\title{
PROSPEK PENGEMBANGAN KEWIRAUSAHAAN SOSIAL MELALUI DIVERSIFIKASI PRODUK SEPEDA KESEIMBANGAN DAN PERLUASAN PEMASARAN DI BANYUMAS
}

\author{
Wahyu Tri Cahyanto ${ }^{1)}$, Aris Haryadi ${ }^{2}$, Hartono ${ }^{3)}$ \\ ${ }^{1,2,3)}$ Fakultas Matematika dan Ilmu Pengetahuan Alam, Universitas Jenderal Soedirman \\ e-mail: wahyu.cahyanto@unsoed.ac.id
}

\begin{abstract}
Abstrak
Telah dilakukan studi mengenai potensi peningkatan pemberdayaan kewirausahaan sosial melalui inovasi teknologi dalam produk kerajinan kayu berupa sepeda keseimbangan, yaitu alat berlatih motorik anak, melalui kerjasama dengan sasaran pengguna. Studi ini merupakan salah satu rangkaian kegiatan dari upaya membagikan ilmu dan teknologi kepada masyarakat untuk meningkatkan nilai ekonomis suatu bahan. Lebih lanjut, pekerjaan ini diharapkan memberikan andil pemikiran untuk solusi penyaluran produk melalui konsep kewirausahaan sosial, yaitu manajemen pemasaran berbasis kerjasama dengan masyarakat sekitar. Metode yang digunakan untuk mencapai tujuan tersebut adalah dengan terjun secara langsung ke masyarakat produsen dengan memberikan pelatihan dan sosialisasi kepada calon pengguna produk. Setelah itu, studi kemungkinan mengenai keberlanjutan program kewirausahaan sosial ini dilakukan dengan observasi langsung dan in depth interview. Hasil analisis menunjukkan adanya tingkat kemungkinan yang tinggi akan keberhasilan program kerjasama antara masyarakat produsen dan pengguna. Selanjutnya, evaluasi kualitas produk dari produsen menunjukkan bahwa saat ini masih diperlukan depth coaching yang lebih supaya dapat menembus pangsa pasar yang lebih tinggi.
\end{abstract}

Kata Kunci : Kewirausahaan sosial, inovasi teknologi, sepeda keseimbangan, manajemen pemasaran

\section{PENDAHULUAN}

Industri rumah tangga merupakan salah satu sektor penguatan ekonomi negara yang sangat penting. Hal ini bisa jadi merupakan faktor utama bagi tegaknya perekonomian negara Indonesia, mengingat banyaknya pelaku ekonomi grass root yang tidak muncul dalam analisis ekonomi secara umum, tetapi menggerakkan perputaran ekonomi secara signifikan. Oleh sebab itu, perhatian terhadap usaha-usaha kecil dan menengah saat ini semakin besar. Berbagai upaya dilakukan untuk terus menghidupkan sektor ini, terutama dari kalangan praktisi usaha dan juga peneliti kajian ilmiah. Salah satu contoh yang dilakukan di kalangan akademisi kampus adalah dengan program pengabdian kepada masyarakat dengan tujuan untuk meningkatkan nilai tambah dari produk home industry. Sentuhan inovasi teknologi terhadap produk yang sudah ada merupakan salah satu bentuk diversifikasi yang dipercaya dapat menambah nilai ekonomis [Kang dan Lee, 2015]. Hal ini juga penting untuk menghadapi kemungkinan berbagai bentuk disrupsi yang muncul sebagai akibat dari perubahan teknologi secara drastis dari waktu ke waktu, yang menyebabkan ketidakpastian prediksi pengaruh teknologi bagi pola hidup manusia [Armstrong $d k k$, 2014].

Selain inovasi teknologi, diversifikasi juga dapat dilakukan dengan menambah varian dari produk yang sudah ada. Jumlah varian produk bagi sauatu unit usaha, tidak peduli usaha skala besar maupun kecil, akan mempengaruhi volume penjualan. Volume penjualan ini selanjutnya akan memengaruhi keuntungan bersih yang dihasilkan. Sebagai contoh yang akan diangkat dalam paper ini industri rumah tangga kerajinan kayu yang hanya membuat dan menjual sangkar burung di Banyumas. Dengan pola satu jenis produk dan satu skema penjualan yang ada, maka volume penjualan dan keuntungan yang diperoleh akan berada pada rentang nilai yang sama. Berangkat dari kenyataan ini, penulis mencoba memberikan gagasan sekaligus menginisiasi perluasan produk dan pemasaran. Seperti halnya usaha kerajinan rotan di Sumatera Selatan yang telah menggunakan strategi pembeda dan penganekaragaman produk kerajinan rotan [Tarida, 2012], maka hal ini juga diujicobakan di wilayah Banyumas. Pada paper ini akan dianalisis 
strategi diversifikasi produk kerajinan kayu di Banyumas, dengan penambahan jenis produk berupa sepeda keseimbangan dan sekaligus target pasar baru. Produk baru dibuat dan dipoles dengan teknologi sensor, sedangkan pasar baru dicari dengan strategi kerjasama dengan elemen masyarakat pengguna utama paling potensial, yaitu lembaga Pendidikan Anak Usia Dini (PAUD). Selanjutnya, potensi keberlangsungan usaha ini dibahas secara kualiatif.

\section{METODE KEGIATAN}

Untuk mencapai tujuan dari kegiatan ini, yaitu mengetahui potensi penggunaan strategi diversifikasi produk dan perluasan pemasaran pada peningkatan volume penjualan maupun penumbuhan unit usaha baru, penulis menggunakan metode analisa kualitatif terhadap parameter-parameter yang digunakan.

\subsection{Pengamatan langsung}

Pengamatan langsung dilakukan terhadap mitra pengrajin kayu yang dicobakan strategi diversifikasi jenis produk. Setelah diberi pelatihan pembuatan sepeda keseimbangan, mulai dari pemilihan bahan sampai pada finishing barang baru, dan didampingi pembuatannya untuk satu unit sepeda, pengrajin mulai dilepas untuk berkreasi membuat beberapa unit. Pelatihan dan pendampingan dilakukan selama seminggu. Setelah itu, evaluasi dilakukan untuk melihat kualitas hasil produksi sepeda baru yang dibuat secara mandiri. Hal ini menentukan pasar yang sesuai untuk menjual produk-produk tersebut karena mutu barang akan menentukan pasarnya.

\subsection{In-depth interview}

Metode ini merupakan cara pengambilan data dengan mewawancarai secara mendalam terhadap fokus masalah yang dituju dengan bebas dan terbuka. Metode ini dilakukan pada pihak pengguna produk sepeda keseimbangan untuk menilai respon pengguna terhadap barang baru, terkait dengan antusiasme konsumtif dan distribusi kembali. Selanjutnya, hasil gabungan dari observasi kedua belah pihak diambil kesimpulan potensi strategi yang ditawarkan terhadap keberlanjutan usaha mandiri sosia

\section{IIII. HASIL DAN PEMBAHASAN}

\subsection{Diversifikasi Produk: Materi Pelatihan Pembuatan Sepeda Keseimbangan}

Kegiatan ini merupakan proses infiltrasi pengetahuan dan keterampilan pembuatan produk baru dari kerajinan kayu. Produk yang biasanya berupa olahan kayu menjadi sangkar burung dikembangkan menjadi olahan kayu dalam bentuk yang sama sekali berbeda, yaitu sepeda keseombangan. Desain sepeda keseimbangan ini menggunakan konsep pusat massa untuk keseimbangan statik [Jones, 2006] serta pengontrol keseimbangan saat bergerak [Rozenblat, 2016; Zirbel1 $d k k, 2016]$. Pelatihan dilakukan di rumah pengrajin yang memang memiliki tempat khusus untuk kegiatan pertukangan. Pemilihan bahan kayu diberikan sebagai materi awal karena menyangkut kekuatan bahan dan porsi keseimbangan. Pemilihan kayu dilakukan berdasarkan ketebalan dan arah serat kayu. Kayu dengan tebal $2 \mathrm{~cm}$ untuk rangka dan fork sepeda, sementara yang memiliki ketebalan 3 $\mathrm{cm}$ untuk stang dan sadel. Untuk kekuatan rangka dipilih kayu yang sesuai dengan arah serat. Setelah itu, kayu dihaluskan dan dipotong sesuai ukuran yang diinginkan. Untuk anak-anak Indonesia, diperkirakan ukuran rangka $65 \times 10 \mathrm{~cm}$, dan ukuran fork $50 \times 5 \mathrm{~cm}$. Titik berat masing-masing balok kayu ditentukan dengan perhitungan titik pusat massa sebagai $q_{\mathrm{PM}}=\frac{1}{m} \sum_{i=1}^{n} m_{i} q_{i}$. Dari konsep seperti ini dapat dikembangkan untuk desain sepeda keseimbangan dengan memperhitungkan keseimbangan aerodinamis dan dinamika sepeda [Epema $d k k, 2012]$.

Langkah selanjutnya adalah latihan pemotongan kayu. Tahapan pemotogan kayu dimulai dengan pemotongan bagian utama yang bergaris lurus dengan gergaji, sedangkan untuk garis lekukan menggunakan alat pemotong scroll saw atau jig saw. Untuk setang yang berbentuk pipa digunakan mesin bubut. Setelah kayu dipotong-potong sesuai mal, maka dilakukan pengeboran untuk tempat baut dan as setang. Pengeboran harus dilakukan secara presisi karena hal ini menentukan simetri dari sepeda. Pengeboran dilakukan dengan mesin bor duduk dan diklem cukup kuat untuk 
mempertahankan posisi kayu. Setelah terbentuk potongan-potongan kayu dengan dudukan mur-baut, maka bisa dilakukan perakitan. Yang perlu diperhatikan dalam perakitan ini adalah pada setiap bagian rangka baut perlu dikencangkan. Roda disetel dengan kencang, tidak goyang, dan mudah menggelinding. Untuk keamanan saat pemakaian, baut-baut yang panjang perlu dirapihkan dengan cara dipotong dan dihaluskan. Perputaran setang juga perlu dipastikan kencang, tidak goyang, dan mudah diputar. Selanjutnya baut as roda perlu diklem dengan lem yang kuat supaya tidak mudah lepas. Langkah terakhir adalah penghalusan dengan amplas, pengecatan, dan pemasangan sarung sadel sepeda. Pengecatan teknik sanding melamine digunakan untuk mempertahankan warna kayu dan tahan noda. Gambar 1 adalah desain sepeda keseimbangan.

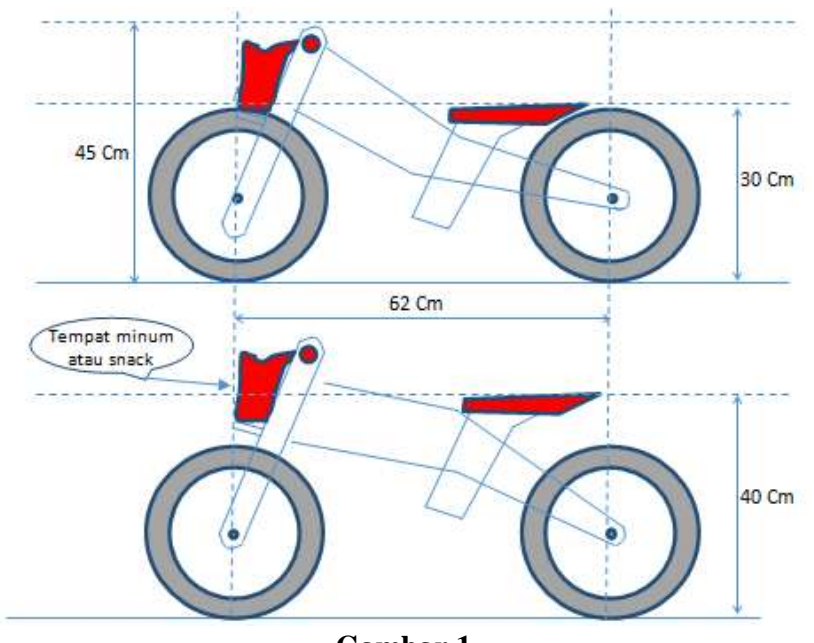

Desain sepeda keseimbangan

Modifikasi lain yang dilakukan adalah menambahkan speedometer pada sepeda keseimbangan. Speedometer yang digunakan adalah jenis digital yang menarik dan mudah dipasang pada sepeda tersebut. Diagram blok rancangan speedometer digital yang digunakan seperti terlihat pada Gambar 2.

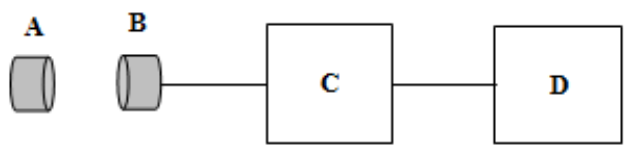

Gambar 2

Diagram blok rancangan speedometer digital
Bagian A merupakan magnet permanen yang digunakan untuk menghasilkan medan magnet yang akan dideteksi oleh sensor magnetik. Magnet permanen ini dipasang pada salah satu bagian jarijari roda yang akan perputar. Sedangkan bagian B merupakan modul sensor magnetik yang akan merespon setiap kali terjadi perubahan medan magnet. Sensor magnetik dipasang pada salah satu bagian rangka yang menahan poros roda. Pemasangan sensor magnetik pada saat tertentu harus dapat berhadapan langsung dengan magnet permanen. Sensor ini akan memberikan keluaran logika tinggi setiap kali berhadapan dengan magnet permanen. Logika tinggi yang dihasilkan oleh sensor digunakan sebagai trigger bagi mikrokontroller untuk mulai menghitung waktu. Lebih lanjut, bagian $\mathbf{C}$ merupakan mikrokontroller yang bertugas menghitung waktu antara trigger sensor yang bertama dan berikutnya. Jeda waktu antara dua trigger merupakan satu langkah putaran roda. Waktu ini digunakan untuk menentukan kecepatan dari putaran roda sepeda. Selanjutnya kecepatan putaran roda dapat dikonversi menjadi kecepatan translasi. Terakhir, bagian D merupakan display yang digunakan untuk menampilkan nilai kecepatan dari sepeda.

Jika diperlihatkan rangkaian lengkap speedometer akan tampak seperti pada Gambar 3 . Modul sensor magnetik bekerja berdasarkan konsep efek Hall. Modul sensor akan memberikan keluaran logika tinggi apabila sensor efek Hall merespon adanya medan magnet. Sensitivitas sensor dapat diatur untuk menyesuaikan kepekaannya terhadap medan magnet permanen yang dipasang. Sinyal keluaran yang berlogika tinggi selanjutnya diumpan ke pin digital dari mikrokontrol arduino nano.

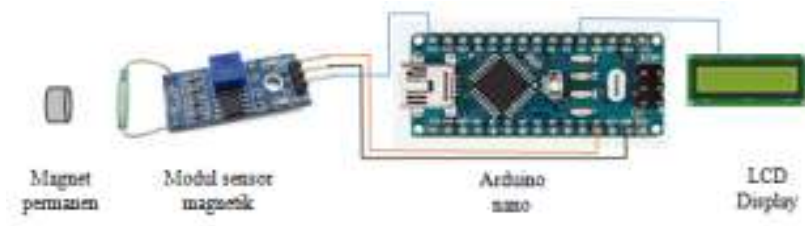

Gambar 3.

Rangkaian speedometer digital

Mikrokontrol merupakan sebuah unit yang dapat diprogram untuk menangani tugas-tugas yang dikehendaki. Arduino nano adalah salah satu jenis 
mikrokontrol yang sangat sederhana tetapi sudah cukup untuk menangani tugas-tugas ringan seperti dalam hal ini untuk menampilkan nilai kecepatan. Arduino nano yang digunakan terlebih dahulu diprogram untuk menentukan interval waktu antara trigger pertama dan berikutnya. Loop kedua dari program adalah untuk menghitung kecepatan berdasarkan pada interval waktu yang sudah direkam sebelumnya. Hasil perhitungan kecepatan selanjutnya ditampilkan pada layar LCD display. Arduino nano dipilih dengan pertimbangan dimensinya dan konsumsi energi listrik yang kecil.

Diversifikasi produk berupa penambahan produk baru sekaligus inovasi dibidang elektronik dan sensor menambah volume penjualan. Hal ini teramati dengan jelas pada awal ketiadaan produk menjadi kemunculan produk baru. Selanjutnya, masalah yang dihadapi adalah tentang pemasaran produk tersebut. Untuk mengatasi masalah ini, tentu saja hal pertama yang dilakukan adalah evaluasi kualitas produk yang dapat dicapai. Dari hasil pengamatan yang dilakukan penggagas, pelatih, dan juga penulis naskah ini menunjukkan bahwa hasil yang dicapai pada pembuatan sepuluh unit sepeda keseimbangan pertama ini cocok untuk pasar kelas menengah ke bawah. Untuk menembus pemasaran ke supermarket masih diperlukan pemolesan dan penghalusan produk. Dalam hal ini, bentuk pengawasan maupun pembinaan lebih lanjut sangat diperlukan.

\subsection{Strategi Diversifikasi Pemasaran Ke Sasaran Pengguna Potensial}

Untuk mencapai peningkatan hasil usaha berupa penambahan laba, maka diperlukan kemampuan menjual produk. Jika dikaitkan dengan prinsip-prinsip matriks Ansoff dalam menetapkan sasaran pemasaran [Ansoff, 1957], yaitu menjual produk yang ada ke pasar yang sudah ada, memperluas produk yang sudah ada ke pasar baru, menambah produk baru untuk pasar yang sudah ada, serta menjual probuk baru ke pasar baru maka yang dilakukan produsen sepeda keseimbangan ini adalah menggunakan strategi ke empat. Dengan melihat kualitas produk yang dapat dihasilkan, maka dipilihlah lembaga PAUD sebagai sasaran pengguna potensial. Dalam hal ini, tidak hanya keuntungan produsen yang dikejar dalam kegiatan ini, tapi juga kerjasama antar elemen masyarakat untuk menjalankan usaha. Dengan demikian, lembaga PAUD tidak semata sebagai obyek pengguna, tetapi juga sebagai subyek usaha untuk meningkatkan kualitas layanan pendidikan kepada anak didiknya dalam memberikan keterampilan psikomotor. Selain itu, adanya kerjasama wirausaha sosial ini merupakan langkah untuk menjaga keberlangsungan PAUD supaya tetap bertahan seiring berjalannya waktu. Keuntungan yang didapatkan dari penjualan kepada masyarakat sekitar atau lembaga lain ini berkontribusi untuk menopang kebutuhan operasional PAUD, sekaligus menjaga keberlanjutan manfaat PAUD. Konsep kewirausahaan sosial ini dikembangkan dengan dasar bahwa aktivitas yang dilakukan menghasilkan pemberdayaan masyarakat, yaitu meningkatkan kesejahteraan masyarakat sekitar serta memberikan laba finansial bagi PAUD. Tentu saja ini bukanlah hal yang mudah untuk memadukan konsep pemberdayaan masyarakat dengan bisnis. Inilah yang menjadi ciri khas dari kewirausahaan sosial. Kewirausahaan sosial ini juga didasarkan pada potensi PAUD, kondisi masyarakat sekitar, dan juga kualitas produk dari produsen.

Keterlibatan lembaga PAUD dalam kewirausahaan sosial yang bermitra dengan produsen sepeda keseimbangan merupakan usaha yang masih linear dengan fungsi utama lembaga. Salah satu kurikulum yang ada di PAUD adalah membantu siswa didik dalam hal perkembangan motorik kasar. Pelatihan psikomotor adalah "titik awal" dari proses belajar anak-anak [de Camargos dan Maciel, 2016]. Sekolah dan guru, terutama di tahun-tahun awal, memiliki peran penting dalam mempengaruhi langsung terhadap perkembangannya. Bunda PAUD merupakan figur kedua setelah orangtua dalam pengawasan perkembangan anak usia dini. Oleh sebab itu, dengan dibekali pendidikan keahlian bidang perkembangan anak, bunda PAUD akan lebih tahu hal-hal apa saja yang dibutuhkan bagi perkembangan siswa didik. Teknik yang bisa digunakan untuk mengembangkan potensi psikomotorik anak yang efisien diantaranya adalah latihan fisik dengan model permainan. Dalam penelitian Kashi $d k k$ tahun 2015, ditemukan bahwa 
aktivitas fisik menaikkan keterampilan psikomotor, dan berbagai aspek kesahatan psikologi dan mental. Salah satu bentuk perminan yang ditawarkan dalam upaya optimalisasi perkembangan psikomotorik anak adalah sepeda keseimbangan. Aspek permainan yang melatih keseimbangan dan peningkatan motorik ini juga dapat digunakan oleh anak-anak dengan keterlambatan perkembangan fisik [Urlich $d k k, 2011]$. Optimalnya perkembangan psikomotorik pada anak ini sangat penting karena merupakan salah satu faktor yang mendukung kemampuan belajar dan bekerjanya. Sesuai namanya, sepeda keseimbangan paling utama akan membantu perkembangan anak dalam menguasai keseimbangan tubuh dan gerakan. Kemampuan keseimbangan anak dalam hal ini akan dilatih dengan sepeda keseimbangan tanpa pedal. Anakanak menggunakan kaki mereka untuk menjaga keseimbangan dan menggerakkannya. Sepeda tanpa pedal ini dimaksudkan agar konsentrasi anak tidak terpecah antara menjaga keseimbangan dengan mengayuh sepeda. Sepeda ini mudah dikendarai, berbentuk lucu yang menyenangkan anak-anak, dan bagus untuk mereka yang belum bisa mengayuh pedal. Sepeda keseimbangan membangun keterampilan motor, kesadaran spasial, keseimbangan, kelincahan, kekuatan inti, dan koordinasi. Alat ini juga membantu meningkatkan dan menjaga kepercayaan diri anak-anak sebagaimana mereka mengontrol gerakan sepeda. Peran bunda PAUD disini adalah mengamati dari dekat dalam pelaksanaan latihan, mengikuti gerakan lajunya sepeda untuk melihat kemajuan anak, serta harus kreatif dalam menentukan jenis latihan. Perlunya bunda PAUD masuk dalam permainan ini dikarenakan anak-anak biasanya cenderung lebih kreatif saat orangtua atau guru mereka ikut aktif dalam permainan.

Dari uraian jenis produk dan peran alami PAUD, maka pemilihan produsen menjadikan lembaga PAUD sebagai mitra merupakan pilihan yang tepat sebagai pasar baru. Hal ini tidak bertentangan dengan fungsi utama lembaga, akan tetapi justru mendukung fungsi utamanya. Bagi pengrajin sepeda keseimbangan sendiri, mengembangkan produk baru dengan memasarkan di tempat yang baru merupakan strategi untuk menaikkan penetrasi pasar. Di samping itu, kerjasama yang saling menguntungkan juga dapat dilakukan dengan cara menjual dengan harga dibawah pasar umum oleh produsen dan PAUD menangkap sebagai penghematan sarana operasional pelaksanaan kurikulum PAUD.

\subsection{Potensi Pengembangan Wirausaha Sosial Sepeda Keseimbangan}

Setelah melihat dari sisi produsen sebagai pegembang baru dalam usaha produksi sepeda keseimbangan dan PAUD sebagai lembaga pengguna produk dari produsen, selanjutnya diuraikan potensi pengembangan wirausaha ini. Dari pengamatan langsung terhadap kualitas produk yang dihasilkan pada awal-awal produksi, tampak bahwa pemasaran yang dilakukan saat ini lebih tepat pada konsumen menengah umum. Memasarkan produk lewat PAUD dengan cara menurunkan harga sedikit dibawah harga supermarket akan menghasilkan volume penjualan optimal. Dari interview dengan pengelola dan bunda PAUD serta orangtua siswa didik PAUD didapatkan data yang dirangkum dalam Tabel 1.

Tabel 1

Tingkat antusiasme PAUD terhadap produk sepeda keseimbangan

\begin{tabular}{|c|c|c|c|c|}
\hline \multirow[t]{2}{*}{ No. } & \multirow{2}{*}{$\begin{array}{l}\text { Parameter prospek } \\
\text { keberlanjutan usaha }\end{array}$} & \multicolumn{3}{|c|}{$\begin{array}{c}\text { Respon pengelola dan orangtua } \\
\text { siswa PAUD }\end{array}$} \\
\hline & & Tinggi & Sedang & Kurang \\
\hline 1 & $\begin{array}{l}\text { Banyaknya pertanyaan harga } \\
\text { beli dari produsen dan harga } \\
\text { jualkembali }\end{array}$ & $\mathrm{x}$ & & \\
\hline 2 & $\begin{array}{l}\text { Ramainya antrian perminj aman } \\
\text { sepeda oleh orangtua siswa } \\
\text { PAUD }\end{array}$ & $\mathrm{x}$ & I & \\
\hline 3 & $\begin{array}{l}\text { Tingkat keterampilan siswa } \\
\text { bersepeda setelahberlatih }\end{array}$ & $\mathrm{X}$ & & \\
\hline 4 & $\begin{array}{l}\text { Tingkat ketangkasan dan } \\
\text { kelincahandalambergerak } \\
\text { setelah berlatih }\end{array}$ & $\mathrm{x}$ & & \\
\hline 5 & $\begin{array}{l}\text { Frekuensi siswa PAUD } \\
\text { bermain HP dan menonton TV }\end{array}$ & & & $\mathrm{x}$ \\
\hline
\end{tabular}

Dari Tabel 1 tampak bahwa penerimaan PAUD terhadap produk baru sepeda keseimbangan cukup baik. Respon siswa terhadap manfaat dari berlatih sepeda keseimbangan juga sangat baik. Hal ini ditandai dengan meningkatnya keterampilan bersepeda dengan sepeda sesungguhnya setelah berlatih sepeda keseimbangan. Dari interview juga dicatat bahwa sepeda keseimbangan ini juga dipinjamkan kepada saudara dari siswa didik PAUD yang berumur di bawah lima tahun. Hal ini menunjukkan pemilihan lembaga PAUD sebagai 
pengguna sekaligus mitra dalam pemasaran cukup efektif. Setidaknya, promosi kepada orangtua siswa PAUD dan masyarakat sekitar lembaga PAUD dapat dilakukan dengan mudah. Dengan demikian, pengenalan produk ke masyarakat luas menjadi lebih cepat. Adapun strategi yang dapat dilakukan untuk keberlanjutan wirausaha sosial ini adalah sebagai berikut.

1. Menempatkan PAUD sebagai pengguna dan mitra usaha dari pengrajin sepeda keseimbangan.

Sebagai mitra usaha, produsen memberikan harga lebih murah saat menjual barangnya. Sebagai pengguna, PAUD akan memperoleh penghematan anggaran untuk operasional pelatihan motorik kasar siswa didik. Sebagai mitra, PAUD dapat malakukan promosi sepeda keseimbangan ke masyarakat luas melalui jaringan yang sudah dimilikinya. Sebagai konsekuensinya, produsen memberikan insentif dari setiap unit penjualan.

2. Menjadikan bisnis sepeda keseimbangan sebagai salah satu unit usaha PAUD untuk membiayai keberlanjutan lembaga.

Seperti yang telah dilakukan oleh penulis, tim kegiatan ini telah memberikan pelatihan kepada staf PAUD dan juga masyarakat sekitar yang tertarik dengan pertukangan kayu. Produsen dapat memberikan franchise (izin membuat dengan produk yang sama) dan memasarkannya. Dengan demikian, produsen lama dan pelaku baru dari PAUD dapat berupaya untuk mengembangkan produk dengan inovasi model-model baru.

Berdasarkan analisis dari sisi produsen, pengguna, dan strategi yang mungkin dijalankan, prospek pengembangan wirausaha sosial sepeda keseimbangan memiliki potensi yang cukup tinggi. Hal yang dapat disarankan adalah memperbaiki kualitas produk yang ada dengan terus melakukan produksi serta menjaga komunikasi antara produsen lama dan mitra barunya.

\section{KESIMPULAN DAN SARAN}

Telah dilakukan kegiatan rintisan berupa diversifikasi produk kerajinan kayu pada industri rumah tangga. Diversifikasi dilakukan dalam bentuk pengadaan produk baru, inovasi teknologi, dan area pemasaran baru. Volume penjualan secara alami meningkat dengan adanya produk baru. Selanjutnya, dari hasil analisis kualitatif terhadap prospek wirausaha sosial sepeda keseimbangan didapatkan kesimpulan adanya pemungkinan tinggi untuk mengembangkan usaha tersebut dengan masing-masing menjaga komitmen.

\section{UCAPAN TERIMA KASIH}

Penulis mengucapkan terima kasih kepada Direktorat Riset dan Pengabdian Masyarakat, Direktorat Jenderal Penguatan Riset dan Pengembangan, Kementrian Riset dan Pendidikan Tinggi, Republik Indonesia atas dukungan dana melalui hibah Program Kemitraan Masyarakat dengan kontrak No. 2045/UN23.14/PM/2018.

\section{REFERENSI}

Ansoff, I., 1957, Strategies for Diversification, Harvard Business Review 35 (5), pp. 113-124.

Armstrong, S., Sotala, K., and ÓhĖigeartaigh, S.S., 2014, The errors, insights and lessons of famous AI predictions - and what they mean for the future, Journal of Experimental and Theoretical Artificial Intelligence 26 (3), pp. 317-342.

de Camargos, E.K., Maciel, R.M., 2016, The importance of psychomotricity in children education, Multidisciplinary Core Scientific Journal of Knowledge 9, pp. 254-275.

Epema, H.K., van den Brand, S., Gregoor, W., Kooijman, J.D.G., Pereboom, H.P., Wielemaker, D.C., van der Zweep, C-J., 2012, Bicycle Design: A different approach to improving on the world human powered speed records, Procedia Engineering 34, pp. 313-318.

Jones, D. E. H., 2006, The stability of the bicycle, Physics Today September 2006, pp. 51-56.

Kang, K.H., and Lee, S., 2015, Effects of diversification strategies on US restaurant firms' performance, Tourism Economics 21 (4), pp. 807-831.

Kashi, A., Sheikh, M., Dadkhah, A., Hemayattalab, R., dan Arabameri, E., 2015, The effect of "Kashi Practices" on the improvement of 
psycho-motor kkills in people with down syndrome, Iranian Rehabilitation Journal $\mathbf{1 3}$ (3), pp. 13-21.

Rozenblat, G.M., 2016, The controlled motion of a bicycle, Journal of Applied Mathematics and Mechanics 80 (2), pp. 133-140.

Tarida, Y., 2012, Strategi Diferensiasi Produk, Diversifikasi Produk, Harga Jual dan Kaitannya
Terhadap Penjualan Pada Industri Kerajinan Rotan di Kota Palembang, Journal of Economic \& Development 10 (2), pp. 124-142.

Zirbel1, S.A., Tolman, K.A., Trease, B.P., Howell, L.L., 2016, Bistable Mechanisms for Space Applications, PLoS ONE 11(12), e0168218. 